\title{
A 2D-QSPR approach to predict blood-brain barrier penetration of drugs acting on the central nervous system
}

\author{
Matheus Malta de Sá, Kerly Fernanda Mesquita Pasqualoto, Carlota de Oliveira Rangel-Yagui*
}

\author{
Department of Pharmacy, Faculty of Pharmaceutical Sciences, University of São Paulo
}

\begin{abstract}
Drugs acting on the central nervous system (CNS) have to cross the blood-brain barrier (BBB) in order to perform their pharmacological actions. Passive BBB diffusion can be partially expressed by the blood/ brain partition coefficient $(\log B B)$. As the experimental evaluation of $\log B B$ is time and cost consuming, theoretical methods such as quantitative structure-property relationships (QSPR) can be useful to predict $\operatorname{logBB}$ values. In this study, a 2D-QSPR approach was applied to a set of 28 drugs acting on the CNS, using the $\log \mathrm{BB}$ property as biological data. The best QSPR model $\left[\mathrm{n}=21, r=0.94\left(r^{2}=0.88\right), s=0.28\right.$, and $\left.Q^{2}=0.82\right]$ presented three molecular descriptors: calculated $n$-octanol/water partition coefficient $(\mathrm{C} \log \mathrm{P})$, polar surface area $(\mathrm{PSA})$, and polarizability $(\alpha)$. Six out of the seven compounds from the test set were well predicted, which corresponds to good external predictability $(85.7 \%)$. These findings can be helpful to guide future approaches regarding those molecular descriptors which must be considered for estimating the $\log \mathrm{BB}$ property, and also for predicting the BBB crossing ability for molecules structurally related to the investigated set.
\end{abstract}

Uniterms: Two-dimensional quantitative structure-property relationships (2D-QSPR). Calculated $n$-octanol/water partition coefficient $(\mathrm{C} \log \mathrm{P})$. Blood-brain barrier. Benzodiazepines.

Fármacos que atuam no sistema nervoso central (SNC) devem atravessar a barreira hematoencefálica (BHE) para exercerem suas ações farmacológicas. A difusão passiva através da BHE pode ser parcialmente expressa pelo coeficiente de partição entre os compartimentos encefálico e sanguíneo (logBB, brain/blood partition coefficient). Considerando-se que a avaliação experimental de $\log B \mathrm{~B}$ é dispendiosa e demorada, métodos teóricos como estudos das relações entre estrutura química e propriedade (QSPR, Quantitative Structure-Property Relationships) podem ser utilizados na previsão dos valores de logBB. Neste estudo, uma abordagem de QSPR-2D foi aplicada a um conjunto de 28 moléculas com ação central, usando $\operatorname{logBB}$ como propriedade biológica. O melhor modelo de QSPR [ $\mathrm{n}=21, r=0,94\left(r^{2}=0,88\right), s=0,28 \mathrm{e}$ $\left.Q^{2}=0,82\right]$ apresentou três descritores moleculares: o coeficiente calculado de partição $n$-octanol/água $(C \log P)$, área de superfície polar (PSA) e polarizabilidade $(\alpha)$. Seis dos sete compostos do conjunto de avaliação foram bem previstos pelo modelo, o que corresponde a um bom poder de previsão externa $(85,7 \%)$. Os resultados obtidos podem auxiliar de forma relevante em estudos futuros, orientando quais descritores moleculares devem ser considerados para estimar $\operatorname{logBB}$ e prever a passagem através da BHE de moléculas estruturalmente relacionadas às do conjunto investigado.

Unitermos: Relações quantitativas bidimensionais entre estrutura química e propriedade (2D-QSPR). Coeficiente calculado de partição $n$-octanol/água (ClogP). Barreira hematoencefálica. Benzodiazepínicos.

\section{INTRODUCTION}

The distribution of many drugs to the brain is significantly different from that occurring in other organs, owing

*Correspondence: C. O. Rangel-Yagui. Departamento de Farmácia, Faculdade de Ciências Farmacêuticas, Universidade de São Paulo. Av. Prof. Lineu Prestes, 580 - Bloco 15 - 05508-950 - São Paulo, SP. E-mail: corangel@usp.br to the presence of the blood-brain barrier (BBB). This consists of a specialized system of capillary endothelial cells that protects the brain against harmful substances in the blood stream, while supplies this organ with the required nutrients for its proper functions (Escuder-Gilabert et al., 2004).

The BBB plays an important role in maintaining homeostasis, separating the brain from systemic circulation. 
Its endothelial cells have tight junctions, promoting a very high transendothelial resistance $\left(1500-2000 \Omega \mathrm{cm}^{2}\right)$, preventing paracellular passage of hydrophilic solutes (Misra et al., 2003). Furthermore, a number of neuroanatomical structures, including catabolic enzymes, efflux transporters and astrocytes prolongations, provide a restricted diffusion of chemical compounds through the brain (Misra et al., 2003; Hitchcock, 2008; Habgood et al., 2000).

Passive diffusion through the BBB is the primary process of many therapeutic compounds' translocation from blood to brain. This step is one of the most critical pharmacokinetic issues in the designing of drug candidates for action on the Central Nervous System (CNS). If the drug cannot cross the BBB, no biological effect in the CNS is observed. This penetration is also a concern in the development of other classes of drugs, for which penetration through the $\mathrm{BBB}$ could result in toxicity due to undesirable effects on nervous tissues (Li et al., 2005; Katritzky et al., 2006).

Although some drugs use transporters, most of them can enter the brain by passive diffusion through the endothelial cells. One of the main important drug properties governing passive diffusions is lipophilicity. In general, the more lipid soluble the molecule, the more easily it will move from the blood to the brain, crossing the endothelial cell membranes. Lipophilicity can be expressed by the $n$ octanol/water partition coefficient $(\log \mathrm{P})$, which represents the relative affinity of a molecule between organic and aqueous media (Misra et al., 2003; Habgood et al., 2000; Goodwin et al., 2005). Other important molecular features, considering passive diffusion, include molecular size (with a cut-off value of 400-700 Da) and intermolecular interaction forces (which express the relative affinity to lipophilic or hydrophilic solvent) (Habgood et al., 2000; Misra et al., 2003; Iyer et al., 2002).

The relative affinity of a molecule between blood and brain can be expressed in terms of the blood/brain partition coefficient $(\log \mathrm{BB})$, according to Equation 1:

$$
\log B B=\log \left(\frac{C_{\text {brain }}}{C_{\text {blood }}}\right)
$$

In Equation 1, $\mathrm{C}_{\text {brain }}$ and $\mathrm{C}_{\text {blood }}$ are the equilibrium concentrations of a molecule in the brain and the blood, respectively (Katritzky et al., 2006). However, this experimental determination is time and cost consuming, preventing extended applications. Therefore, computerassisted drug design methodologies (CADD), such as quantitative structure-property and/or structure-activity relationship studies (QSPR and QSAR, respectively), may help to estimate biological data, reducing synthetic steps, predicting pharmacokinetic and pharmacodynamic profiles, constituting an important tool in the design and development of new drugs and novel leads (Katritzky et al., 2006). A literature review reported several studies, carried out on a number of different chemical structures, and in which 2D and 3D QSPR models have been proposed to predict $\log B \mathrm{~B}$ values (Katritzky et al., 2006; Van Damme et al., 2008; Iyer et al., 2002; Konovalov et al., 2007; Subramanian et al., 2003; Zhao et al., 2007; Zhang et al., 2008; Narayanan et al., 2005). Some of these models show a correlation between $\log \mathrm{BB}$ and some physicochemical parameters, such as molecular refractivity (MR), molecular volume $(\mathrm{V})$, acid ionization constant $\left(\mathrm{K}_{\mathrm{a}}\right.$ and $\mathrm{pK}_{\mathrm{a}}$ ), thermodynamic parameters (solvation energy, etc.), polar surface area (PSA), and others. (Chen et al., 2009; Clark, 1999). Nevertheless, easy interpretable mathematical models, with good internal and external predictability, are still needed for some specific drug classes. Against this background, in the present study a two-dimensional (2D) QSPR approach was applied to a set of 28 structurally similar molecules including benzodiazepines, tricyclic compounds and their metabolites, with CNS activity as antidepressant and neuroleptic, in order to build a QSPR model able to predict $\log B \mathrm{~B}$ values and also provide relevant findings about the BBB crossing ability of other compounds structurally related to the investigated set.

\section{MATERIAL AND METHODS}

A set of 28 molecules, including benzodiazepines, tricyclic compounds and their metabolites, were selected from Katritzky et al. (Katritzky el al., 2006). Their structural similarity is based on the presence of an azepine or isosteric ring bound to at least one aromatic ring. The experimental $\operatorname{logBB}$ values were assessed using animal models and synthesized radio-labeled compounds. Often, this measure is based on the degree of BBB penetration, defined as the ratio of the steady-state molar concentration of the drug molecule (radio-labeled) in the brain and in the blood (Katritzky et al., 2006). The $\log B B$ values are given in Table 1, comprising the dependent variables of this QSPR analysis. The range of $\log B \mathrm{~B}$ values is from -1.82 to 1.20 .

The molecules were randomly divided into two sets. The training set was composed of 21 compounds whereas seven compounds were used for the external validation (test set). The test set compounds were not included in the development of the 2D-QSPR models.

The three-dimensional structures of each of the 28 molecules were built in their neutral forms employing the HyperChem 7.51 software (Hypercube Inc., 2003). The 
TABLE I - Chemical structures and $\operatorname{logBB}$ experimental values (logBBexp) found for training and test sets (Katritzky et al., 2006). The test set compounds are marked with an asterisk $(*)$

\section{Compounds \\ 1. alprazolam}

2. oxazepam

3. midazolam

4. M1-L663-581

5. M2-L663-581

6. L663-581

7. diazepam

8. bretazenil

9. flumazenil

10. Ro 19-4603

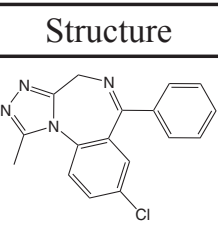

$\log \mathrm{BB}$

0.04

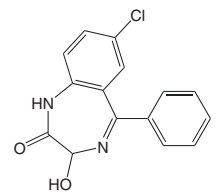

0.61<smiles>Cc1ncc2n1-c1ccc(Cl)cc1C(c1ccccc1F)=NC2</smiles>

0.36

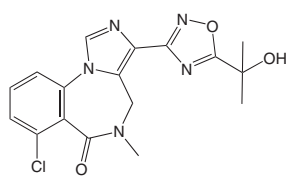

$-1.34$

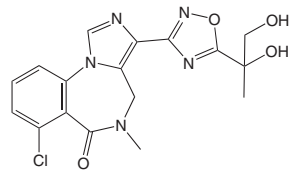

$-1.82$

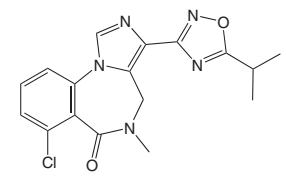

$-0.30$<smiles>CN1C(=O)CN=C(c2ccccc2)c2cc(Cl)ccc21</smiles>

0.52

$-0.09$
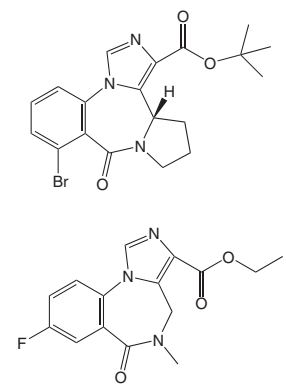

$-0.25$
17. demethylclobazam

Compounds

11. demethyldiazepam

12. 1-OH-midazolam

13. 4-OH-midazolam

14. triazolam

15. clobazam

16. flunitrazepam<smiles>CN1C(=O)CN=C(c2ccccc2F)c2cc([N+](=O)[O-])ccc21</smiles>

0.06<smiles>O=C1CC(=O)N(c2ccccc2)c2cc(Cl)ccc2N1</smiles>

0.36

18. mianserin<smiles>CN1CCN2c3ccccc3Cc3ccccc3C2C1</smiles>

19. desipramine

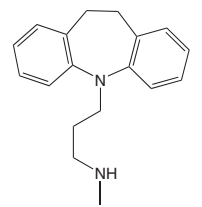


TABLE I - Chemical structures and $\operatorname{logBB}$ experimental values (logBBexp) found for training and test sets (Katritzky et al., 2006). The test set compounds are marked with an asterisk $(*)$ (cont.)

Compounds
20. amitriptyline
24. $N$-demethyl
23. mirtazapine*

crystallized structures of the drugs diazepam and imipramine were retrieved from the Protein Data Bank (PDB) (Bernstein et al., 1977) [entry codes 2bxf, resolution 2.95 $\AA$ (Ghuman et al., 2005); and 2q72, resolution $1.70 \AA$ (Singh et al., 2007)] and used as the starting geometries to construct all benzodiazepines and tricyclic compounds, respectively. Each 3D-model had its geometry optimized by HyperChem 7.51, using MM+ force field without any restriction (Allinger, 1977), followed by the AM1 semiempirical quantum method (Dewar et al., 1985). Partial atomic charges were calculated using the AM1 semiempirical method, also implemented by the HyperChem 7.51 program (Hypercube Inc, 2003).

As mentioned above, the structures modeled were used to calculate the molecular descriptors or independent variables used in this study, employing HyperChem 7.51 (Hypercube Inc, 2003) and MarvinBeans 4.1.8 software (ChemAxon Ltd, 1998-2009) (see Table II).

A preliminary systematic search of the most signifi-

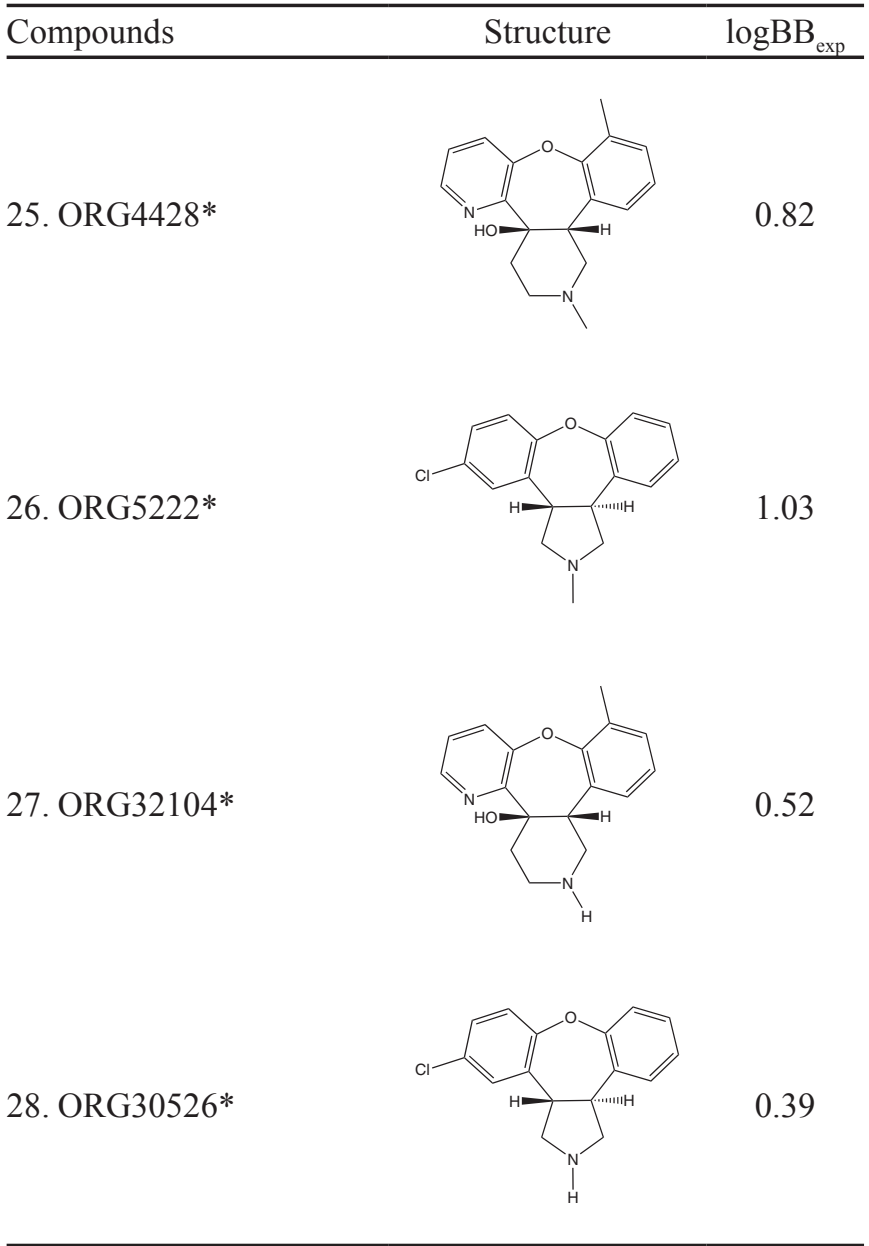

cant independent variables was carried out based on their distribution or variability against the biological property (visual inspections) using scatter plots [Pirouette ${ }^{\circledR} 3.11$ (Infometrix, Inc., 1990-2003)]. Therefore, the scatter plots of $\operatorname{logBB}$ versus the calculated molecular descriptors aided in the decision concerning which molecular descriptors would be more relevant in describing the biological property.

TABLE II - Molecular descriptors calculated using HyperChem ${ }^{\circledR}$ 7.51 and MarvinBeans 4.1.8 software

\begin{tabular}{ll}
\hline Software & Molecular Descriptors \\
\hline HyperChem® 7.51 & $\begin{array}{l}\text { solvent-accessible surface area } \\
\text { (Aprox.), solvent-accessible surface } \\
\text { area (Grid), van der Waals volume, } \\
\text { solvent-accessible volume. }\end{array}$ \\
\hline MarvinBeans 4.1.8 & $\begin{array}{l}\text { ClogP, polarizability ( } \alpha \text { ), polar surface } \\
\text { area (PSA), H-bond donor, H-bond } \\
\text { acceptor, molar refractivity (MR) }\end{array}$ \\
\hline
\end{tabular}


The selected descriptors were used to build the 2D-QSPR models employing multiple linear regression (MLR) and leave-one-out (LOO) cross-validation method, performed by BuildQSAR ${ }^{\circledR}$ 1.0.0 software (Oliveira, Gaudio, 2003). Due to the relatively small size of the training set $(n=21)$, the statistical restriction which imposes a limit from four up to five observations (compounds) per descriptor or independent variable (Ferreira, 2002; Tavares, 2004) were respected in this approach and a maximum of four molecular descriptors per model was considered.

Statistical measures of significance including the LOO cross-validation coefficient $\left(Q^{2}\right)$, linear regression coefficient ( $r$ or $\left.r^{2}\right)$, standard deviation $(s)$, Fischer's value $(F)$ and standard predictive residual sum of squares value $\left(s_{\text {PRESS }}\right)$ were used to evaluate the robustness of the QSPR models. Moreover, a linear cross-correlation matrix of the descriptors was computed to verify if the independent variables were correlated to one another or otherwise. Pairs of descriptors which are highly correlated $(R \approx 1)$ to one another are deemed to provide nearly the same information to the model, while poorly correlated pairs of descriptors $(R<0.5)$ give distinct contribution to the model.

The differences between the experimental or observed $\left(\log \mathrm{BB}_{\text {exp }}\right)$ and calculated or predicted $\left(\log \mathrm{BB}_{\text {pred }}\right)$ properties are called residual values. In this study, the compounds of the training set for which the absolute residual values exceeded two standard deviation (SD) from the mean of a model, were considered as outliers. This threshold corresponds to a significance level of ninety-five percent (Ferreira et al., 1999).

As mentioned previously, the seven compounds of the test set were not included in the build of the QSPR models, but were used to validate the best QSPR model constructed from the training set, and to evaluate its prediction capacity. The predicted $\log B \mathrm{~B}$ value of each compound in the test set was calculated using the equation of the best model by substitution of the molecular descriptors' calculated values. The absolute residual values should not be higher than one SD from the mean of the model, which corresponds to a significance level of ninety-nine percent.

\section{RESULTS AND DISCUSSION}

\section{Molecular descriptor selection}

The proper selection of molecular descriptors, i.e., those truly relevant in describing the studied property or biological activity, is a challenge in QSPR/QSAR studies, since the amount of information generated by the available software is sometimes enormous and hard to comprehend (van de Waterbeemd, Rose, 2008). In this study, the cal- culated molecular descriptors were related to lipophilicity $(\mathrm{Clog} \mathrm{P})$, intrinsic properties, such as molecular size and shape [volume $(\mathrm{V})$, surface area] and electronic, topologic and mixed parameters [polarizability $(\alpha)$, number of H-bond acceptor and donor sites, polar surface area (PSA) and molar refractivity (MR)]. The polar surface area (PSA) calculation is defined as the sum of the surface of all the polar atoms of the molecule, especially $\mathrm{N}$ and $\mathrm{O}$, including $\mathrm{H}$ atoms. The estimation of topological polar surface area (TPSA) was based on the method described by Ertl, 2000 (Ertl et al., 2000). This method, implemented in MarvinBeans software (ChemAxon Ltd, 1998-2009), provides results which are practically identical to the 3D PSA, while the TPSA is approximately 100 -times faster. Thus, the $2 \mathrm{D}$ representation is an approximation of the 3D PSA (Ertl, 2007).

As described in the Material and Methods Section, the scatter plots of $\log \mathrm{BB}$ versus each of the calculated molecular descriptors were employed as preliminary selection criterion (data not shown). The most relevant independent variables, which were used to generate the QSPR models, presented a good dispersion of the data related to the variability of the biological property. Linear and non-linear tendencies were both considered. Only the number of $\mathrm{H}$-bond acceptor and donor sites did not provide a suitable dispersion of data considering the variability of the $\log \mathrm{BB}$ values and were therefore not included in the generation of the QSPR models.

\section{D-QSPR models}

All the best fit models were linear given the $\mathrm{Clog} P$ values' range was not larger than four logarithmic units. Thus, parabolic or bilinear functions were not considered (Patrick, 2008). The resulting 2D-QSPR models are listed below.

Model 1:

$\log \mathrm{BB}=+0.47( \pm 0.11) \mathrm{C} \log \mathrm{P}-0.94( \pm 0.30)$

$n=21 ; r=0.90\left(r^{2}=0.81\right) ; s=0.33 ; F=80.04 ; Q^{2}=0.74$;

$s_{\text {PRESS }}=0.39$

Model 2:

$\log \mathrm{BB}=-0.02( \pm 0.01) \mathrm{PSA}+1.23( \pm 0.32)$

$n=21 ; r=0.89\left(r^{2}=0.79\right) ; s=0.35 ; F=68.52 ; Q^{2}=0.72$;

$s_{\text {PRESS }}=0.40$

Model 3:

$\log \mathrm{BB}=+0.28( \pm 0.24) \mathrm{C} \log \mathrm{P}-0.01( \pm 0.01) \mathrm{PSA}-0.03$

$( \pm 1.13)$

$n=21 ; r=0.91\left(r^{2}=0.83\right) ; s=0.32 ; F=45.90 ; Q^{2}=0.78$;

$s_{\text {PRESS }}=0.38$ 


\section{Model 4}

$\log \mathrm{BB}=+0.24( \pm 0.22) \mathrm{C} \log \mathrm{P}-0.05( \pm 0.04) \alpha-0.01$ $( \pm 0.01) \mathrm{PSA}+1.76( \pm 1.92)$

$n=21 ; r=0.94\left(r^{2}=0.88\right) ; s=0.28 ; F=39.74 ; Q^{2}=0.82$; $s_{\text {PRESS }}=0.34$

Model 5:

$\log \mathrm{BB}=+0.21( \pm 0.22) \mathrm{C} \log \mathrm{P}-0.01( \pm 0.01) \mathrm{PSA}-0.03$ $( \pm 0.01) \mathrm{MR}+1.41( \pm 1.54)$

$n=21 ; r=0.94\left(r^{2}=0.88\right) ; s=0.28 ; F=42.10 ; Q^{2}=0.83$;

$s_{\text {PRESS }}=0.33$

All the models presented $r$ values higher than 0.8 , indicating well fitting models. Models 4 and 5 had the highest $r$ values $\left(0.94 ; r^{2}=0.88\right)$ and the lowest $s$ values $(0.28)$. However, the $s$ value is better evaluated when the dependent variable's standard deviation is also given, and should be smaller than the latter (Patrick, 2008). For $\operatorname{logBB}$, specifically, the standard deviation is not currently reported (Abraham et al., 2006).

The highest $F$ values were obtained from models 1 and 2 (80.04 and 68.52, respectively). It is noteworthy that the $F$ value decreases as the number of descriptors in the model increases, indicating a substantial loss of statistical significance. This is likely due to the total number of compounds in the training set $(n=21)$.

The internal predictability of a model is expressed by the LOO cross-validation correlation coefficient $\left(Q^{2}\right)$, which is a very important statistical measure of QSPR/ QSAR models. The $Q^{2}$ values for all models were higher than 0.5 . Models 4 and 5 presented the highest $Q^{2}$ values ( 0.82 and 0.83 , respectively).

Taking into account the evaluation of all statistical parameters measured, models 4 and 5 were considered the best QSPR models. Both equations presented three independent variables, but model 4 has $\alpha$ instead of MR. These two descriptors are indeed related to each other, since MR can express both steric and electronic effects. Hence, a linear cross-correlation matrix of the descriptors of models 4 and 5 was computed, using BuildQSAR $\AA$ 1.0 .0 , to verify if the independent variables were correlated to one another or otherwise (see Table III). As mentioned previously, pairs of descriptors that are highly correlated $(R \approx 1)$ to one another are deemed to provide nearly the same information to the model, while poorly correlated pairs of descriptors $(R<0.5)$ give distinct contribution to the model.

According to the results presented in Table 3, ClogP and PSA are highly correlated $(R=0.82)$, meaning they provide almost the same information to both models. However, this correlation value can be understood as a mathe-
TABLE III - Linear cross-correlation matrix found for the molecular descriptors of models 4 and 5

\begin{tabular}{lcccc}
\hline & $\mathrm{Clog} P$ & $\alpha$ & PSA & MR \\
\hline ClogP & $\mathbf{1 . 0 0}$ & 0.06 & 0.82 & 0.26 \\
$\alpha$ & & $\mathbf{1 . 0 0}$ & 0.03 & 0.84 \\
PSA & & & $\mathbf{1 . 0 0}$ & 0.20 \\
MR & & & & $\mathbf{1 . 0 0}$ \\
\hline
\end{tabular}

$\mathrm{C} \log \mathrm{P}=$ calculated $n$-octanol/water partition coefficient; $\mathrm{PSA}=$ polar surface area; $\alpha=$ polarizability; $\mathrm{MR}=$ molar refractivity.

matical artifact since the parameters are not biologically correlated (the former represents a lipophilic parameter, while the latter is a topological descriptor). Moreover, the models presenting both parameters proved to be statistically more significant, indicating the importance of including $\mathrm{ClogP}$ and PSA in the same model. Furthermore, a previous study reported poor intercorrelation between these two data items $(R=0.299)($ Ertl, 2007) reinforcing the mathematical artifact assumption. On the other hand, the MR and $\alpha$ presented a high correlation coefficient $(R$ $=0.84$ ) and are actually correlated. MR is a composite parameter that considers molecular volume and polarization capacity, whereas $\alpha$ represents the relative tendency of a molecular charge distribution to be distorted from its normal shape by an external electric field, which may be caused by the presence of an ion or dipole nearby (Ertl, 2007).

Therefore, models 4 and 5 have relevant independent variables describing the $\log B \mathrm{~B}$ property. The signs of the regression coefficients indicate the direction of the descriptors' contribution to the biological property. A positive sign can be interpreted as a favorable contribution to the biological property $(\mathrm{Clog} P)$ while a negative sign, as being unfavorable (PSA, $\alpha, \mathrm{MR}$ ).

Size and shape were not directly expressed in the 2D-QSPR models. Instead, some descriptors such as MR and PSA consider molecule size or shape in their calculation. Molecular refractivity (MR), as mentioned earlier, for example, considers both molecular volume (and indirectly size and shape) and molecule polarizability capability (Patrick, 2008). Polar surface area (PSA) is another example which considers topological parameters, taking into account the number of polar atoms $(\mathrm{N}, \mathrm{O}$ and $\mathrm{H})$ and is indirectly related to the size of the molecule (Ertl, 2007).

The internal predictability of models 4 and 5 was also explored as described in the Material and Methods section. The results are presented in Tables IV and V, respectively. 
TABLE IV - Residual values found for model 4

\begin{tabular}{|c|c|c|c|}
\hline Compounds & $\operatorname{logBB} B_{\exp }$ & $\log \mathrm{BB}_{\mathrm{pred}}$ & Residual Values $\left(\log \mathrm{BB}_{\mathrm{exp}}-\log \mathrm{BB}_{\mathrm{pred}}\right)$ \\
\hline 1-OH-midazolam & -0.07 & 0.06 & -0.13 \\
\hline 4-OH-midazolam & -0.30 & 0.18 & -0.48 \\
\hline alprazolam & 0.04 & 0.17 & -0.13 \\
\hline amitriptyline & 0.98 & 1.06 & -0.08 \\
\hline bretazenil & -0.09 & -0.43 & 0.34 \\
\hline clobazam & 0.35 & 0.40 & -0.05 \\
\hline desipramine & 1.20 & 0.84 & 0.36 \\
\hline demethylclobazam & 0.36 & 0.46 & -0.10 \\
\hline demethyldiazepam & 0.50 & 0.69 & -0.19 \\
\hline diazepam & 0.52 & 0.63 & -0.11 \\
\hline flumazenil & -0.29 & -0.31 & 0.02 \\
\hline flunitrazepam & 0.06 & 0.09 & -0.03 \\
\hline Imipramine & 0.83 & 0.92 & -0.09 \\
\hline L663-581 & -0.30 & -0.46 & 0.16 \\
\hline M1L663-581 & -1.34 & -1.01 & -0.33 \\
\hline M2L663-581 & -1.82 & -1.51 & -0.32 \\
\hline mianserin & 0.99 & 1.04 & -0.05 \\
\hline midazolam & 0.36 & 0.51 & -0.15 \\
\hline oxazepam & 0.61 & 0.40 & 0.21 \\
\hline Ro19-4603 & -0.25 & -0.69 & 0.44 \\
\hline triazolam & 0.74 & 0.20 & 0.54 \\
\hline
\end{tabular}

Note: $\log \mathrm{BB}_{\text {exp }}=\log \mathrm{BB}$ experimental or observed; $\log \mathrm{BB}_{\text {pred }}=\log \mathrm{BB}$ predicted or calculated; $\mathrm{SD}=$ standard deviation; $2 \mathrm{SD}=$ two standard deviations.

According to Tables 4 and 5, only model 4 proved capable of predicting $\log \mathrm{BB}$ for all compounds of the training set. The absolute residual values did not exceed two SDs from the mean of model 4, meaning there were no outliers. Thus, model 4 was selected as the best 2DQSPR model.

\section{External Validation}

As outlined previously, model 4 was the best fit model selected to describe $\log \mathrm{BB}$ in terms of ClogP, PSA and $\alpha$. The external validation was performed using the test set $(n=7)$. The calculated molecular descriptors present in model 4, the experimental and calculated $\operatorname{logBB}$ values, the respective residual values as well as the SD values obtained from the test set compounds, are listed in Table VI.

Six out of the seven test set compounds were well predicted by model 4 , corresponding to good external predictability $(85.7 \%)$. The residual value of the molecule ORG4428 was not considered statistically significant, since the difference was only in the second decimal. Moreover, the biological measurement of $\log B \mathrm{~B}$ is very susceptible to experimental errors.

The highest absolute residual value in the test set was observed for carbamazepine, which was the only molecule not well predicted by model 4 . However, this drug penetration in the CNS is highly driven by several carriers, specifically the ABC family (ATP-binding cassette), such as the efflux protein P-gp (P-glycoprotein) (Sun et al., 2006). In addition, its pharmacokinetic profile is very complex due to its limited water solubility and capacity of self metabolism induction (Charney et al., 2006). Consequently, carbamazepine's BBB permeation is a composite of several mechanisms and the 2D-QSPR model proposed considers only passive crossing, resulting in differences between the experimental value (which considers all the mechanisms involved) and the predicted value. 
TABLE V - Residual values found for model 5

\begin{tabular}{|c|c|c|c|}
\hline Compounds & $\log \mathrm{BB}_{\exp }$ & $\log B B_{\text {pred }}$ & Residual Values $\left(\log B B_{\text {exp }}-\log B B_{\text {pred }}\right)$ \\
\hline 1-OH-midazolam & -0.07 & -1.65 & 1.58 \\
\hline 4-OH-midazolam & -0.30 & -1.53 & 1.23 \\
\hline alprazolam & 0.04 & -1.53 & 1.57 \\
\hline amitriptyline & 0.98 & -0.71 & 1.69 \\
\hline bretazenil & -0.09 & -2.23 & 2.14 \\
\hline clobazam & 0.35 & -0.89 & 1.24 \\
\hline desipramine & 1.20 & -0.54 & 1.74 \\
\hline demethylclobazam & 0.36 & -0.83 & 1.19 \\
\hline demethyldiazepam & 0.50 & -0.63 & 1.13 \\
\hline diazepam & 0.52 & -0.68 & 1.20 \\
\hline flumazenil & -0.29 & -1.84 & 1.55 \\
\hline flunitrazepam & 0.06 & -1.31 & 1.37 \\
\hline imipramine & 0.83 & -0.53 & 1.36 \\
\hline L663-581 & -0.30 & -2.51 & 2.21 \\
\hline M1L663-581 & -1.34 & -3.04 & 1.70 \\
\hline M2L663-581 & -1.82 & -3.52 & 1.70 \\
\hline mianserin & 0.99 & -0.35 & 1.34 \\
\hline midazolam & 0.36 & -1.22 & 1.58 \\
\hline oxazepam & 0.61 & -0.92 & 1.53 \\
\hline Ro19-4603 & -0.25 & -2.26 & 2.01 \\
\hline \multirow[t]{2}{*}{ triazolam } & 0.74 & -1.57 & 2.31 \\
\hline & & & $\mathrm{SD}=0.35 ; 2 \mathrm{SD}=0.69$ \\
\hline
\end{tabular}

Note: $\log \mathrm{BB}_{\text {exp }}=\log \mathrm{BB}$ experimental or observed; $\log \mathrm{BB}_{\text {pred }}=\log \mathrm{BB}$ predicted or calculated; $\mathrm{SD}=$ standard deviation; $2 \mathrm{SD}=$ two standard deviations.

TABLE VI - Molecular descriptors of the best QSPR model (model 4), the experimental and calculated $\operatorname{logBB}$ values, the residual values and the respective $\mathrm{SD}$ value found for the test set compounds

\begin{tabular}{lcccccc}
\hline Compounds & ClogP & PSA $\left(\AA^{2}\right)$ & $\alpha\left(\AA^{3}\right)$ & $\operatorname{logBB} B_{\text {exp }}$ & $\operatorname{logBB} B_{\text {pred }}$ & $\begin{array}{c}\text { Residual Values } \\
\left(\operatorname{logBB} B_{\text {exp }}-\operatorname{logBB} B_{\text {pred }}\right)\end{array}$ \\
\hline carbamazepine & 3.22 & 46.33 & 26.95 & 0.00 & 0.72 & -0.72 \\
mirtazepine & 3.38 & 19.37 & 31.23 & 0.53 & 0.82 & -0.29 \\
$N$-demethyldesipramine & 3.24 & 29.26 & 30.98 & 1.06 & 0.70 & 0.36 \\
ORG4428 & 2.49 & 32.70 & 34.11 & 0.82 & 0.33 & 0.49 \\
ORG5222 & 3.10 & 12.47 & 29.83 & 1.03 & 0.89 & 0.14 \\
ORG32104 & 2.25 & 41.49 & 32.26 & 0.52 & 0.27 & 0.25 \\
ORG30526 & 2.74 & 21.26 & 27.99 & 0.39 & 0.81 & -0.42 \\
& & & & & & SD $=\mathbf{0 . 4 5}$
\end{tabular}

Note $\mathrm{C} \log \mathrm{P}=$ calculated $n$-octanol/water partition coefficient; PSA = polar surface area; $\alpha=$ polarizability; $\log \mathrm{BB}_{\text {exp }}=\operatorname{logBB}$ experimental or observed; $\log \mathrm{BB}_{\text {pred }}=\log \mathrm{BB}$ predicted or calculated; $\mathrm{SD}=$ standard deviation.

\section{CONCLUSION}

The present study employed a set of 21 molecules to build 2D-QSPR models in order to predict BBB passive permeation, i.e., the mechanism proposed is the passive diffusion of the molecules through the BBB. The whole approach and methodology are simple and easy to interpret. Nevertheless, the models obtained were robust 
and presented suitable internal predictability. The best fit model (model 4) had three descriptors, ClogP, PSA and $\alpha$, which are well-known parameters and strongly influence BBB passive crossing. It is known that lipophilicity is a determining factor in drugs pharmacokinetics, influencing biological membrane permeation. The ClogP contribution to the models was positive in all the cases, suggesting that lipophilic moieties, that increase this parameter, facilitate passive translocation. By contrast, polar moieties seem to restrict molecule entry to the CNS. Quantitatively, this behavior is expressed by PSA and $\alpha$, which contribute negatively to BBB diffusion. Published data has described linear models to explain the passive crossing through the $\mathrm{BBB}$. The lipophilic characteristic has been described as the main factor that drives the passive diffusion from the blood into the cells and, in this case, the crossing through the BBB. As stated previously, the literature also reports other important parameters that seem to be related to the blood-brain partition $(\log B B)$ : capability of forming hydrogen bonds, molecular flexibility, ability to bind to the lipophilic membrane, acid ionization constant $\left(\mathrm{K}_{\mathrm{a}}\right.$ and $\mathrm{pK}_{\mathrm{a}}$ ), thermodynamic parameters (solvation energy, etc.), molecular refractivity (MR), molecular volume (V), polar surface area (PSA) and other electronic and topologic parameters. Nevertheless, the model presented in this study is comparable or better than other published 2D-QSAR BBB models and show similar descriptors used by other authors. (Norinder et al., 2002; Katritzky et al., 2006; van Damme et al., 2008; Iyer et al., 2002; Konovalov et al., 2007; Subramanian et al., 2003; Zhao et al., 2007; Zhang et al., 2008; Narayanan et al., 2005; Young et al., 1988; Abraham, 2004; Goodwin et al., 2005). These findings can help future decisions about which groups are favorable or otherwise for CNS entry by BBB permeation, based on the physicochemical properties evaluated here. Additionally, due to its excellent external predictability, the best fit model can be applied to predict the $\log B \mathrm{~B}$ property of other compounds with the same structural motif, such as an azepine or isosteric ring bound to at least one aromatic ring.

\section{ACKNOWLEDGMENTS}

The authors would like to thank FAPESP (State of São Paulo Research Foundation) and CNPq (National Council for Scientific and Technological Development) for the financial support, as well as the Molecular Modeling Laboratory - LAPEN, under the supervision of Prof. Elizabeth Igne Ferreira, for providing the resources that were used in this study.

\section{REFERENCES}

ABRAHAM, M.H.; IBRAHIM, A.; ZHAO, Y.; ACREE Jr., W.E. A data base for partition of volatile organic compounds and drugs from blood/plasma/serum to brain, and an LFER analysis of the data. J. Pharm. Sci., v.95, n.10, p.2091-2100, 2006.

ALLINGER, N.L. Conformational Analysis 130. MM2. A Hydrocarbon Force Field Utilizing V1 and V2 Torsional Terms. J. Am. Chem. Soc., v.99, n.25, p.8127-8137, 1977.

BERNSTEIN, F.C.; KOETZLE, T.F.; WILLIAMS, G.J.B.; MEYER, E.F. JR.; BRICE, M.D.; RODGERS, J.R.; KENNARD, O.; SHIMANOUCHI, T.; TASUMI, M. The Protein Data Bank: a computer-based archival file for macromolecular structures. J. Mol. Biol., v.112, n.3, p.535-542, 1977.

CHARNEY, D.S.; MIHIC, S.J.; HARRIS, R.A. Hypnotics and Sedatives. In: BRUNTON, L.L.; LAZO, J.S.; PARKER, K.L., (Eds.). Goodman \& Gilman's: The pharmacological basis of therapeutics. 11.ed. New York: McGraw-Hill, 2006. cap. 16. 1 CD-ROM.

CHEMAXON LTD. Marvinbeans Program Release 4.1.8. for Windows. Máramaros köz 3/a, 1037 Budapest, Hungary, 1998-2009. (Conjunto de dados. Ambiente operacional).

CHEN, Y.; ZHU, Q.J.; PAN, J.; YANG, Y.; WU, X.P. A prediction model for blood-brain barrier permeation and analysis on its parameter biologically. Comput. Methods Progr. Biomed., v.95, n.3, p.280-287, 2009.

CLARK, D.E. Rapid calculation of polar molecular surface area and its application to the prediction of transport phenomena. 2. Prediction of blood-brain barrier penetration. J. Pharm. Sci., v.88, n.8, p.815-821, 1999.

DEWAR, M. J. S.; ZOEBISCH, E. G.; HEALY, E. F.; STEWART, J. J. P. AM1: A new general purpose quantum mechanical molecular model. J. Am. Chem. Soc., v.107, n.13, p.3902-3909, 1985.

ERTL, P. Polar Surface Area. In: MANNHOLD, R.; KUBINYI, H.; FOLKERS, G. (Eds.). Molecular drug properties. Weinheim: Wiley-VCH, 2007. v.37, cap.5, p.111-126.

ERTL, P.; ROHDE, B.; SELZER, P.; Fast Calculation of Molecular Polar Surface Area and its Application on the Prediction of Drug Transport Properties. J. Med. Chem., v.43, n.20, p.3714-3717, 2000. 
ESCUDER-GILABERT, L.; MOLERO-MONFORT, M.; VILLANUEVA-CAMAÑAS, R.M.; SAGRADO, S.; MEDINA-HERNÁNDEZ, M.J. Potential of biopartitioning micellar chromatography as an in vitro technique for predicting drug penetration across the blood-brain barrier. J. Chromatogr. B. Anal. Technol. Biomed. Life Sci., v.807, n.2, p.193-201, 2004.

FERREIRA, M.M.C. Multivariate QSAR. J. Braz. Chem. Soc., v.13, n.6, p.742-753, 2002.

FERREIRA, M.M.C.; ANTUNES, A.M.; MELGO, M.S.; VOLPE, P.L.O. Quimiometria I: calibração multivariada, um tutorial. Quim. Nova, v.22, n.5, p.724-731, 1999.

GHUMAN, J.; ZUNSZAIN, P.A.; PETITPAS, I.; BHATTACHARYA, A.A.; OTAGIRI, M.; CURRY, S. Structural basis of the drug-binding specificity of human serum albumin. J. Mol. Biol., v.353, n.1, p.38-52, 2005.

GOODWIN, J.T.; CLARK, D.E.; In silico predictions of bloodbrain barrier penetration: considerations to "keep in mind". J. Pharmacol. Exp. Ther., v.315, n.2, p.477-483, 2005.

HABGOOD, M.D.; BEGLEY, D.J.;ABBOTT, N.J. Determinants of passive Drug Entry into the Central Nervous System. Cell Mol. Neurobiol., v.20, n.2, p.231-253, 2000.

HITCHCOCK, S.A. Blood-brain barrier permeability considerations for CNS-targeted compound library design. Curr. Opin. Chem. Biol., v.12, n.3, p.318-323, 2008.

HYPERCUBE INC. Hyperchem Program Release 7.51 for Windows, Gainesville, FL, 2002. (Conjunto de dados. Ambiente operacional).

INFOMETRIX, INC. Pirouette 3.11, Woodinville, WA, 1990 2003. (Conjunto de dados. Ambiente operacional).

IYER, M.; MISHRA, R.; HAN, Y.; HOPFINGER, A.J. Predicting blood-brain barrier partitioning of organic molecules using membrane-interaction QSAR analysis. Pharm. Res., v.19, n.11, p.1611-1621, 2002.

KATRITZKY, A.R., KUANAR, M.; SLAVOV, S.; DOBCHEV, D.A.; FARA, D.C.; KARELSON, M.; ACREE, W.E.Jr.; SOLOV'EV, V.P.; VARNEK, A. Correlation of bloodbrain penetration using structural descriptors. Bioorg. Med. Chem., v.14, n.14, p.4888-4917, 2006.
KONOVALOV, D.A.; COOMANS, D.; DECONINCK, E.; HEYDEN, Y.V.; Benchmarking of QSAR models for bloodbrain barrier permeation. J. Chem. Inf. Model, v.47, n.4, p.1648-1656, 2007.

LI, H.; YAP, C.W.; UNG, C.Y.; XUE, Y.; CAO, Z.W.; CHEN, Y.Z. Effects of Selection of Molecular Descriptors on the Prediction of Blood-Brain Barrier Penetration and Nonpenetrating Agents by Statistical Learning Methods. $J$. Chem. Inf. Model, v.45, n.5, p.1376-1384, 2005.

MISRA, A.; GANESH, S.; SHAHIWALA, A.; SHAH, S.P. Drug delivery to the central nervous system: a review. J. Pharm. Pharm. Sci., v.6, n.2, p.252-273, 2003.

NARAYANAN, R.; GUNTURI, S.B. In silico ADME modelling: prediction models for blood-brain barrier permeability using a systematic variable selection method. Bioorg. Med. Chem., v.13, n.8, p.3017-3028, 2005.

NORINDER, U.; HAEBERLEIN, M. Computational approaches to the prediction of the blood-brain distribution. Adv. Drug Deliv. Rev. v.54, n.3, p.291-313, 2002.

OLIVEIRA, D.B.; GAUDIO, A.C. BuildQSAR: A new computer program for QSAR analysis. QSAR Comb.Sci., v.19, n.6, p.599-601, 2003.

PATRICK, G. L. An introduction to medicinal chemistry. 4.ed. Oxford University Press: Oxford, 2008. 752 p.

SINGH, S.K.; YAMASHITA, A.; GOUAUX, E. Antidepressant binding site in a bacterial homologue of neurotransmitter transporters. Nature, v.448, n.7156, p.952-956, 2007.

SUBRAMANIAN, G.; KITCHEN, D.B. Computational models to predict blood-brain barrier permeation and CNS activity. J. Comput. Aided Mol. Des., v.17, n.10, p.643-664, 2003.

SUN, J.J.; XIE, L.; LIU, X.D. Transport of carbamazepine and drug interactions at blood-brain barrier. Acta Pharmacol. Sin., v.27, n.2, p.249-253, 2006.

TAVARES, L.C., QSAR: AAbordagem de Hansch. Quim. Nova, v.27, n.4, p.631-639, 2004

VAN DAMME, S.; LANGENAEKER, W.; BULTINCK, P. Prediction of blood-brain partitioning: A model based on ab initio calculated quantum chemical descriptors. J. Mol. Graph Model., v.26, n.8, p.1223-1236, 2008. 
VAN DE WATERBEEMD, H.; ROSE, S. Quantitative Approaches to Structure-Activity Relationship. In: WERMUTH, C.G. (Ed.). The practice of medicinal chemistry. 3.ed. New York: Academic Press, 2008. cap. 23,29 .

YOUNG, R.C.; MITCHELL, R.C.; BROWN, T.H.; GANELLIN, C.R.; GRIFFITHS, R.; JONES, M.; RANA, K.K.; SAUNDERS, D.; SMITH, I.R.; SORE, N.E. Development of a new physicochemical model for brain penetration and its application to the design of centrally acting $\mathrm{H} 2$ receptor histamine antagonists. J. Med. Chem., v.31, n.3, p.656-671, 1988.
ZHANG, L.; ZHU, H.; OPREA, T.I.; GOLBRAIKH, A.; TROPSHA, A. QSAR modeling of the blood-brain barrier permeability for diverse organic compounds. Pharm. Res., v.25, n.8, p.1902-1914, 2008.

ZHAO, Y.H.; ABRAHAM, M.H.; IBRAHIM, A.; FISH, P.V.; COLE, S.; LEWIS, M.L.; DE GROOT, M.J.; REYNOLDS, D.P. Predicting penetration across the blood-brain barrier from simple descriptors and fragmentation schemes. $J$. Chem. Inf. Model., v.47, n.1, p.170-175, 2007.

Received for publication on $02^{\text {nd }}$ October 2009. Accepted for publication on $07^{\text {th }}$ July 2010 . 